\title{
Sternal Talon, a novel repair for sternal dehiscence
}

\author{
Thavakumar Subramaniam, Luther Keita, Dave Veerasingam \\ Department of Cardiothoracic Surgery, Galway University Hospital, Ireland \\ Kardiochirurgia i Torakochirurgia Polska 2015; 12 (2): 153-154
}

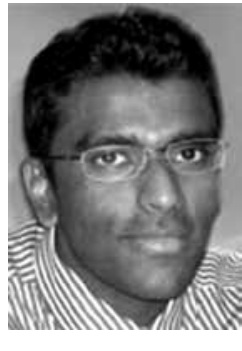

\begin{abstract}
Sternal dehiscence is a recognised complication after median sternotomy, occurring in $0.5-5 \%$ of cases with or without infection.

A 72-year-old man presenting with collapse and ventricular tachycardia was investigated for a possible acute cardiac event 2 years after coronary artery bypass grafting for ischemic heart disease. Work-up chest X-ray showed displacement of all sternal wires, and computed tomography (CT) performed to investigate further showed sternal dehiscence with right ventricle wall herniation through the defect and sternal wire breakdown. A decision was made after discussion with the patient to repair the defect using 3 Sternal Talon devices and 2 sternal wires. The patient made an uncomplicated recovery, and the outpatient clinic review after discharge home showed satisfactory and stable sternal union. We report a case of noninfected sternal dehiscence managed successfully with the Sternal Talon without long-term complications.
\end{abstract}

Key words: Sternal Talon, sternal dehiscence.

A 72-year-old man was brought in by ambulance following collapse after tying his shoe. The electrocardiogram showed ventricular tachycardia. The patient had undergone an uncomplicated coronary bypass grafting 2 years prior to admission and had been asymptomatic with no limitations of daily living. This prompted us to investigate the patient for a possible acute cardiac event, and a repeat coronary angiogram was performed. Investigation showed no significant occlusion to coronary vessels including grafted vessels. Echocardiography showed good left ventricular (LV) function with ejection fraction (EF) at > 55\% with no valvular pathology. The superficial surgical wound healed without complications.

Admission chest $X$-ray showed displacement of all sternal wires. This was clinically supported with an unstable sternum with no superficial wound complications. Computed tomography (CT) of thorax with intravenous (IV) contrast was performed to investigate further.

\section{Streszczenie}

Rozejście się mostka jest znanym powikłaniem po sternotomii pośrodkowej występującym w 0,5-5\% przypadków z infekcją lub bez niej.

Pacjent w wieku 72 lat z objawami zapaści i częstoskurczu komorowego został przebadany pod kątem możliwych ostrych zdarzeń sercowych 2 lata po przejściu operacji pomostowania aortalno-wieńcowego z powodu choroby niedokrwiennej serca. Badanie radiologiczne klatki piersiowej wykazało przemieszczenie się wszystkich pętli zespalających mostek, a tomografia komputerowa (TK) wykonana w celu dalszych badań uwidoczniła rozejście się mostka z przepukliną ściany prawej komory i rozpadem pętli zespalających mostek. Po konsultacji z pacjentem podjęto decyzję o naprawie ubytku przy użyciu 3 implantów Sternal Talon oraz 2 pętli zespalających mostek. Powrót chorego do zdrowia przebiegł bez powikłań; badania kontrolne przeprowadzone ambulatoryjnie wykazały zadowalające zespolenie mostka. W pracy przedstawiono przypadek rozejścia się mostka bez zakażenia oraz jego udanego leczenia przy użyciu implantów Sternal Talon bez odległych komplikacji. Słowa kluczowe: Sternal Talon, rozejście się mostka.

Both images show sternal dehiscence with right ventricle wall herniation through the defect and sternal wire breakdown.

Ventricular tachycardia resolved with oral amiodarone and bisoprolol. The patient was then referred for cardiothoracic service for repair of the sternal defect.

CT findings were confirmed during surgery, and the right ventricle was mobilised away from the sternal edge and reduced into the mediastinum. The sternum was repaired with 3 Sternal Talons and 2 sternal wires. Open implants were placed in either side of the sternum after accurate approximation of depth and width. All 3 implants were then closed and locked using a screwdriver. Superficial facia and skin were closed in layers after haemostasis was achieved.

The patient was discharged home on day 7 after surgery with no acute complications. Pain was managed well with tapering doses of opioid analgesia with no require- 


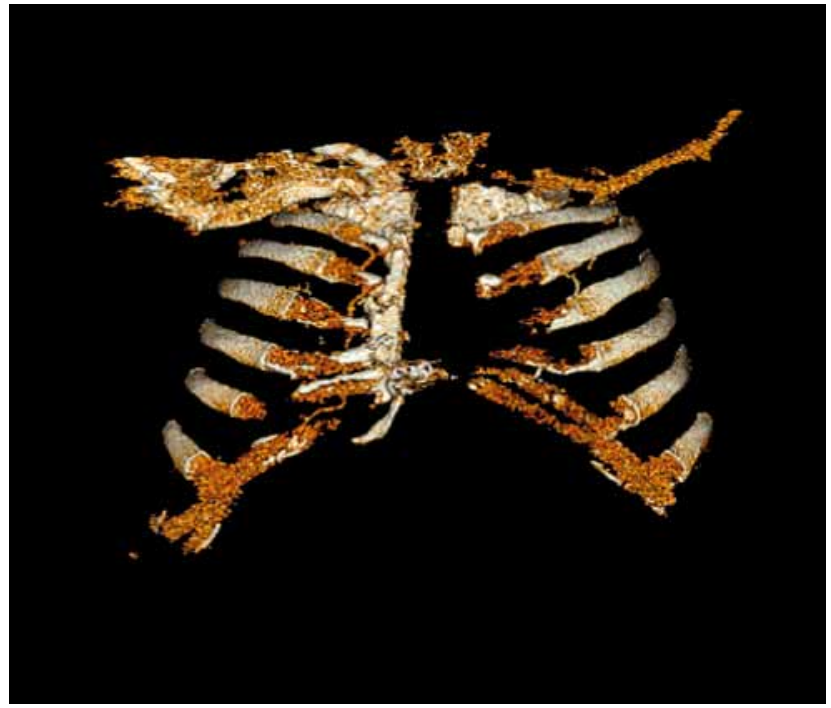

Fig. 1. 3D reconstruction showing sternal dehiscence

ments for long-term analgesia. The patient was reviewed in the outpatient clinic one month after the procedure. The review included clinical examination and chest $\mathrm{X}$-ray with findings that support good sternum union and stability. The patient was reviewed again after 4 months, with no long-term complications.

\section{Discussion}

Median sternotomy for open cardiac procedure is a bone splitting procedure that can be complicated by poor healing, resulting in sternal dehiscence at an incidence of $0.5-5 \%$ with or without infection [1, 2]. Higher risk group are those with obesity, osteoporosis, chronic obstructive pulmonary disease, diabetes mellitus and patients on long-term immunosuppressive drugs [1]. Surgical technique also contributes in particular to off midline sternotomy [1] and poor closure technique. Sternal dehiscence may further complicate the post-operative period with superficial wound infections, mediastinitis, pain, and cardiac and pulmonary function compromise [3].

Repair of sternal dehiscence is guided by radiological and intra-operative findings. In the present case, Robicsek sternal closure was unsuitable due to significant loss of bone. However, the Sternal Talon with wires provided good bony opposition and rigid fixation. Recent publications

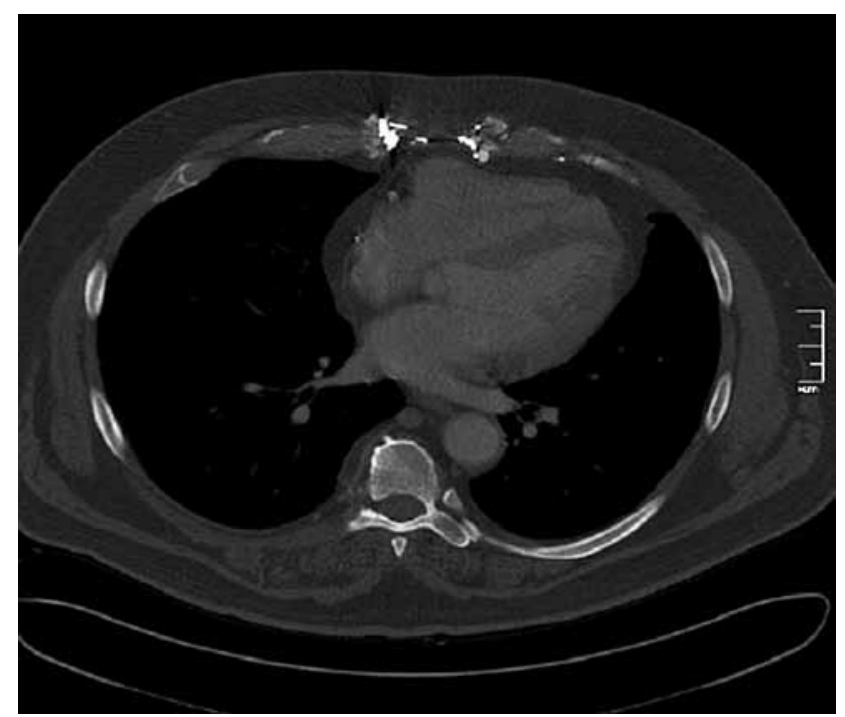

Fig. 2. Non-contrast CT image

have supported the safe use of this novel sternal closure technique, and our patient had successful repair with no reported no long-term complications.

A male and female Sternal Talon component is placed intercostally on either side of split vertical sternal segments following width and depth measurements. Both components are reduced and locked in place to achieve accurate and secure reduction. Long-term removal can be achieved by unlocking the screw after exposure and dissection.

In conclusion, we have reported a case of non-infected sternal dehiscence managed successfully with the Sternal Talon without long-term complications.

\section{Disclosure}

Authors report no conflict of interest.

\section{References}

1. Losanoff JE, Richman BW, Jones JW. Disruption and infection of median sternotomy: a comprehensive review. Eur J Cardiothorac Surg 2002; 21: 831-839.

2. Stahle E, Tammelin A, Bergstrom R, Hambreus A, Nystrom SO, Hansson HE. Sternal wound complications - incidence, microbiology and riskfactors. Eur J Cardiothorac Surg 1997; 11: 1146-1153.

3. Katz NM. Pericostal sutures to reinforce sternal closure after cardiac surgery. J Card Surg 1997; 12: 277-281. 